\title{
Meta
}

Journal des traducteurs

Translators' Journal

\section{Translators and Language Engineering in Nigeria: A Case Study of Nupe Language News Translators}

\section{H. J. Jacob}

Volume 44, numéro 2, juin 1999

URI : https://id.erudit.org/iderudit/003236ar

DOI : https://doi.org/10.7202/003236ar

Aller au sommaire du numéro

Éditeur(s)

Les Presses de l'Université de Montréal

ISSN

0026-0452 (imprimé)

1492-1421 (numérique)

Découvrir la revue

Citer cet article

Jacob, H. J. (1999). Translators and Language Engineering in Nigeria: A Case Study of Nupe Language News Translators. Meta, 44(2), 397-402.

https://doi.org/10.7202/003236ar

\section{Résumé de l'article}

En décrivant certains problèmes de traduction vers la langue nupe du Nigeria, l'auteur aborde une problématique propre à de nombreuses langues africaines : doit-on utiliser la description exhaustive ou carrément l'emprunt lorsqu'on traduit des termes inexistants en langue cible pour un public isolé du monde moderne? 


\section{REFERENCES}

Art h ur , D. (1991): Recruiting, Interviewing, Selecting \& Orienting New Employees, 2nd Ed., American Management Association.

Brennan, J. \& P. M cGevor (1988): Graduates at Work, Jessica Kingsley Publisher.

Hacket $t$, P., Schofield, P. \& M. Armstrong (1982): The Daily Telegraph Recruitment Handbook, The N ew Opportunity Press.

Her riot, P. (1989): Assessment and Selection in Organizations, John Wiley and Sons Limited.

Pear son, R. \& K. Wal sh (1983): How to Analyse Your Local Labour M arket, Gower Publishing Company Limited.

Pl at t, T. E. (1983): In B. Ungerson (Ed.), Recruitment Handbook, Gower Publishing Company Limited.

Pl umpy, P. (1991): Recruitment and Selection, Institute of Personnel Management.

Schnider, B. (1976): Staffing Organizations, Goodyear Publishing Company, Inc.

Ungerson, B. (Ed.) (1983): Recruitment Handbook, Gower Publishing Company Limited.

Walker, A. (1982): Unqualified and Underemployed: Handicapped Young People and the Labour Market, The M acmillan Press Limited.

\section{Translators and Language Engineering in Nigeria: A Case Study of Nupe Language News Translators}

\section{RÉSUMÉ}

En décrivant certains problèmes de traduction vers la langue nupe du Nigeria, l'auteur aborde une problématique propre à de nombreuses langues africaines: doit-on utiliser la description exhaustive ou carrément l'emprunt lorsqu'on traduit des termes inexistants en langue cible pour un public isolé du monde moderne?

\section{ABSTRACT}

In describing certain translation problems incurred in translating into the Nupe language of Nigeria, the author raises a question that is pertinent to a number of African languages: When translating for an audience that is far removed from the modern world, should one resort to exhaustive description or to loan words for terms that are nonexistent in the target languages?

\section{INTRODUCTION}

Language engineering has been defined by Capo (1990: 1) as:

that domain of applied linguistics concerned with the design and implementation of strategies (i.e. the conscious and deliberate steps) toward the rehabilitation and optimal utilization of individual languages. In fact, it is a mechanism of language planning that recognizes problems and proceeds to 'engineer' solutions to such problems.

Language engineering, then, is concerned with the problems of "underdevelopment," so to speak, that a language may be facing. Its aim is to "update" the language concerned in order to, among other things, make it capable of accounting for and communicating "the changing experiences of the speakers as well as all aspects of the human legacy called knowledge" (Capo 1990: 2). As Cyffer (1977 cited by Emenanjo 1990: 89) has noted, the ultimate goal of language engineering is,

the development of a language and if needed be making it suitable for areas in which it has not been used before, e.g. modern education, government, economy and science.

What is immediately obvious is the fact that language engineering is not only a domain in which translators are actively involved, but also one in which they have a vital role to play. Since translation is an act of communication par excellence, it reveals the fact that not all languages are similarly able to express ideas, and highlights the problems a particular language may have in expressing certain things. M oreimportant to our discussion here, though, is the fact that translation also contributes to the search for solutions to such problems. The Nigerian translator, for instance, who has to render foreign concepts and notions in his native language often finds that appropriate and adequate terms and expressions are not readily available, if at all. He is thus forced to "engineer" solutions to such problems.

But how successful are Nigerian translators in their attempts to overcome the language related problems they come across? More specifically, to what extent do translators succeed in carrying out their mission when they have to deal with texts containing terms and expressions for which corresponding items are not available in their own language? In this study, an attempt is made to find answers to these questions using the translation of English language news bulletins into Nupe, a language spoken in Nigeria.

\section{THE SITUATION OF NUPE AND THE NEED FOR LANGUAGE ENGINEERING}

Nupe is a "minority" language in Nigeria, so called because of the relatively small number of people who speak it. The Nupes numbered 650,000 in 1963 , growing by 1986 to a population of 1,314,000. These figures can be compared to those for the 
Hausas (the largest linguistic group in Nigeria), who numbered 11,653,000 and 23,233,000 in 1963 and 1986 respectively. It is interesting to note, however, that Nupe is the eleventh most important language in Nigeria (Jibril 1990: 114), a country with about 394 different languages (Hansford et al. 1976). Nupe is thus not such a small language after all and is the "majority" language spoken by the largest linguistic group in Niger State.

What is more, Nupe, unlike the majority of Nigerian languages, has had a written form and been thoroughly described for more than a century. The first recorded collection of Nupe words dates back to 1828-54 when vocabularies were noted in written texts. Since then, a lot of work has been done on the language (Madugu 1985: 25), most recently by the Nupe Language Project Committee set up in 1978 by the Niger State government. It is probably not surprising, then, that Nupe is one of 12 "large" written languages in Nigeria, a nation containing 117 or so written languages (Williamson 1990: 142).

But Nupe remains an "underdeveloped" language, even by Nigerian standards. The language was discriminated against during the colonial era and continues to have marginal status today. No technical terminology has been produced in Nupe for use in primary schools, ${ }^{1}$ despite the fact that it is one of the 27 languages approved by the Federal Government of Nigeria for its mother tongue education policy. ${ }^{2}$

In the face of such official neglect, the responsibility of Nupe speakers is obvious. The onus is on them to keep their language alive by using it all the time and to also get involved in language engineering with the aim of making Nupe acquire the property of "intellectualisation" 3 needed for communicating efficiently in today's rapidly changing world. As a result, Nupe language translators occupy a particularly important place in the scheme of things.

\section{NUPE LANGUAGE NEWS TRANSLATORS AND LANGUAGE ENGINEERING}

The situation of Nupe language translators is essentially the same as that of all other Nigerian language translators. Translators in Nigeria have to struggle to give expression in their languages to things outside the experience of their largely illiterate and rural audiences, and for which corresponding terms are not readily available. Since Nupe is a "minority" language which has not been given the opportunity and encouragement needed to de velop appropriate terminology for many modern concepts and notions, translators using Nupe are forced to resort to language engineering more frequently than those translating into $\mathrm{H}$ ausa,
Igbo and Yoruba (the "majority" languages in Nigeria).

Indeed, when listening to the radio news, for instance, one is struck by the number of items requiring language engineering, as translators are forced to continually improvise solutions to problems posed by the absence of appropriate terms. A good example would be the Gulf War, when translators had to use their own initiative to find ways of expressing terms like the Gulf, missiles, the allied forces, etc. But how likely was it that the Nupe people understood what was being reported? To what extent did translators succeed in informing the Nupe-speaking public about the war? This study will assess the performance of Nupe language translators in rendering foreign concepts and notions, and examine their contribution to the development of the Nupe language.

\section{EVALUATION OF THE WORK OF THE NUPE LANGUAGE NEWS TRANSLATORS}

The investigation and evaluation are based on tape recordings and transcriptions of news aired by $\mathrm{Ra}$ dio Nigeria Kaduna, the most powerful station to broadcast programmes in Nupe. Items were also taken from the news broadcasts of other radio stations (Radio Niger M inna, Radio Niger Bida and Radio Kwara llorin) to illustrate some of the points made.

\subsection{Examples of "engineered" solutions}

The study uses examples from a variety of subject areas as news translators deal with a range of different issues all the time, unliketranslators of other types of texts who often deal with only one domain at a time.

\subsubsection{Government, administration, politics}

Ministry of External Affairs: gwalagi alhamari kin dezhi

Democracy: muliki nya 'za kanma

Apartheid: muliki 'ba yiba

Opposition party: egi tsudo nya enan siyasa

U.S. Secretary of State: man takada wonciko nya America

\subsubsection{Finance, trade and commerce, etc.}

Bank draft: takada cheque na e yi gan bank draft na Trade fair: shianin dzuko lo United Bank for Africa: Banki nya Africa

First Bank: Banki mafari

Shop: kata enya kun ba

\subsubsection{Science and technology}

Computer: injini na e jin lisafi nya ezan tso na Refrigerator: firiji na ela nuwon fu yeko na Missile: agba 
Tear gas: nawu yakagi

Hydrogen: efe nya hydrogen

\subsubsection{Miscellaneous}

Hectare: ezun

Pilot: driva eya fiti

Illegal drugs: cigbe dedezhi

Cocaine: yikuru dede nya cocaine

Director: nusa 'ba wu wonciko

Certificate: takada nya eri nya katun cin

Boxing: eko ce

Kilometre: kilomita

\subsection{Analysis of the solutions found}

\subsubsection{Using the known for the unfamiliar/ unknown/new}

One has to be impressed by the extent to which translators have attempted to use Nupe terms and expressions as often as possible. In most of the examples, direct borrowing of words from other languages are avoided to a large extent, some notable exceptions being hydrogen, cocaine and kilometre (kilomita).

At first glance, then, translators have been able to use the Nupe language to give adequate expression to most of the concepts and notions noted above. On closer examination, however, this turns out to be untrue: the terms the translators use are far from adequate, and are not good translations of the items in question. The use of Nupe words, as we shall try to prove, does not guarantee that translated concepts are adequately and appropriately rendered.

\subsubsection{Use of misleading terms}

The frequent use of misleading terms by translators is evident in the case of missile, translated into Nupe as agba. The Nupe word dates back to the time when the British were waging wars of conquest against the Nupes, using unfamilial weapons for which the Nupes coined the term agba. Although agba is an instrument of war, it is not a term that actually refers to missiles but at best makes one think of artillery. As much as agba may refer to an instrument which fires dangerous projectiles, therefore, the use of the word to refer to missiles is quite misleading. Interestingly, when talking about the now famous Patriot missile, the Nupe translators saw the need to use enya kun (weapon of war), which is vague but has the merit of not confusing the public.

Another example is U.S. Secretary of State, translated into Nupe as man takada wonciko nya kin Amerika. Translated back into English, this literally means the big secretary of America. For a person who may not know the government post being referred to (certainly the case with most of the
Nupes), the idea conveyed is that the personage referred to is the most important of all the secretaries in America. The translators would have done better to think of minista (minister), a term which the Nupe people are familiar with at least vaguely, having heard the term used to refer to a top government functionary, and which gives a more precise idea of the function. Incidentally, minista is the term one of the translators in Kanuda used one day to refer to the function in question. His actual words were: minista alhamari kin dezhi nya America (the American minister of affairs having to do with foreign countries). We see here a good example of what happens on Radio Nigeria Kaduna, where translators seem to rely on their own initiative to find solutions to the problems they encounter.

\subsubsection{Use of vague terms}

Some of the other solutions the translators arrived at are not as misleading as they are vague. For example, illegal drugs has been rendered simply as cigbe dedezhi (bad drugs), while apartheid is translated as muliki eba yiba (the regime that makes life difficult). Similarly, shiani dzuko lo (ceremony during which sales are carried out) does not express the significance the term trade fair would have for an English-speaking audience. The same can be said for director, translated as nusa 'ba wu wonciko (big leader who shows the way); boxing = eko ce (fighting); opposition party = egi tsudo nya enan siyasa (child of the second wife); tear gas = nawu yakagi (peppery smoke); open ballot voting = kuriya ce eye 'go danna eye 'sa danna (the voting that brings the fish face to face with the net); and hectare $=$ ezun (a vague reference to units into which land is divided). The problem is not that the audience receives completely inaccurate information, but that in each of the cases the message lacks precision.

Worse, though, is the situation where, finding no words in Nupe which are appropriate, the translators resort to direct borrowing of foreign words, thereby leaving the audience completely in the dark. The following section discusses such borrowed items.

\subsubsection{Use of borrowed terms}

One major problem is that foreign words are often adopted along with foreign concepts, with no attempt made to clarify what is being referred to. A good example is that of bank draft, translated as takada cheque na e yi gan bank draft na, i.e. the cheque paper that is called bank draft. The translators obviously assumed that all Nupes know what a cheque is and decided to use the word to define another term. They did not get the message across, however. 
But this is not the only source of possible misunderstanding. There are instances where translators use Nupe words to describe things that are foreign, but still fail to give a clear picture of what they are talking about. If we take cocaine, for example, we see that it has been translated as yikuru dede nya cocaine. Now, cocaine is no undoubtedly a powder (yikuru) which is bad (dede), but it is also definately not the only powder that is bad. What is more, the translation gives no indication as to what makes cocaine bad or the extent to which it is dangerous. In any event, the description given is not sufficient to identify the substance. The audience thus obtains little information, just as it learns nothing from efe nya hydrogen (the hydrogen air).

The translators were somewhat more successful when translating refrigerator, rendering it in such a way that it could be understood relatively easily as "the engine that makes water cold" (wato injini na e la nuwon fu yeko na). But here too the translation gives a partial picture of the capabilities of the item in question. The same can be said about the term computer, rendered as injini na e la jin lisafi nya ezan tso na (the engine used to make fast calculations). This remains very abstract for the majority of Nupes (who do not even know what electronic calculators are), and allows only a partial understanding of what a computer can do.

\subsection{Remarks on the appropriateness of the translator' choices and strategies}

These examples allow us to conclude that, on the whole, N upe language news translations are of very low quality when it comes to the manner in which foreign and new concepts are rendered. The examples reveal the lack of an up-to-date and appropriate Nupe vocabulary for many modern concepts and notions that need to be translated daily. To cope with this situation, Nupe language translators usually adopt two main strategies: the explanatory method and borrowing.

Now, there is obviously nothing wrong in adopting these strategies whenever deficiencies in terminology exist in the target language. Indeed, as Jakobson suggested a long time ago (1959: 234),

Whenever there is deficiency, terminology may be qualified and amplified by loanwords or loan-translations, neologisms or semantic shifts, and finally, by circumlocutions.

This, of course, has immediate bearing on the now famous seven procédés techniques which Vinay and Darbelnet (1958) talked about, and which translators to when the need arises.

Although the Nupe translators have adopted some of the most commonly used strategies, they havefailed to produce correct translations; correct- ness being understood here as defined by Nida and Taber (1974: 1):

Correctness must be determined by the extent to which the average reader [listener in our case] for which a translation is intended will be likely to understand it correctly. Moreover, we are not concerned merely with the possibility of his understanding correctly, but with the overwhelming likelihood of it. In other words, we are not content merely to translate so that the average receptor is likely to understand the message; rather we aim to make certain that such a person is very unlikely to misunderstand it.

Evidence that Nupe language news translators produce translations that are not correct in the sense just noted can be seen from the terms and expressions they come up with. Often, these do not give a clear picture of what is being referred to, to say nothing of being misleading or simply impossible to understand. This is particularly true of the translations of terms that are not easy to define. Indeed, we can note that the more acceptable translations are all of easily explainable terms. For example, democracy rendered as muliki nya 'za kanma (the government of the people), certificate = takada nya eri nya katun cin (the paper indicating the end of one's studies) and shop = kata enya kun ba (the "house" where things are sold) are all apt translations. Such examples, however, are few and far between. The audience is left in the dark most of the time.

This raises questions about the wisdom of trying to provide conceptual definitions, or of presenting supposedly salient characteristics of items to be rendered in Nupe. In the first place, the use of the explanatory method does not really make it possible for translators to obtain satisfactory results, especially if they do not understand the concepts to be rendered and so experience difficulties when trying to explain terms. Moreover, one can doubt the appropriateness of the strategy itself. As Antia (1990: 6) points out when discussing Ohly:

The oft-preferred explanatory method in African languages is perhaps based on the wrong notion that every speaker of a language must be at home with ideas in all fields expressed in that language.

To state the obvious, it is inconceivable that every speaker of, say, English will be familiar with all the concepts expressed in that language. Not everybody in the English-speaking world understands every detail of a computer, for instance. H owever, a news broadcast in England or America which mentions the word "computer" will not try to make 
everyone understand every aspect of the device. It is simply taken for granted that those who are not familiar with computers and wish to know more about them will take the trouble to acquire that knowledge on their own. One cannot but wonder, therefore, why Nupe language translators insist on explaining every term. While it is true that the translator's role is to make an audience understand the message contained in the original, the question remains as to whether the target audience needs to show some initiative in the development of comprehension. Peter Newmark (1977: 175) puts it cogently when discussing Nida's dynamic equivalence:

The translation theorist has to raise the question, in considering Nida's dynamic equivalence, not only of the nature (education, class, occupation, age, etc.) of the readers, but of what is to be expected of them. Are they to be handed everything on a plate? Are they to make any effort? Are they ever to look a word up in a dictionary or an encyclopedia?

Although the majority of Nupe speakers are illiterate, they can be expected to make the effort required to find out about items they know little or nothing about. This, of course, depends on whether or not such items are of any interest to them.

The use of borrowed terms can thus be excused and even encouraged, especially when the context can help to clarify the meaning of the term. There is nothing wrong in using kilometre, for example, in a sentence like: ezan na danbo na yi nya kilomita sitsun, i.e. the distance to be covered is one hundred kilometres. But even when context is not helpful, the use of directly borrowed words can still be encouraged for several reasons, the most obvious being that translators can avoid excessively long circumlocutions that add nothing to the translation. As well, the adoption of the explanatory approach de-technicalizes many terms rendered into Nupe. This has the particular disadvantage of making it difficult to derive new words and combinations. How, for example, can translators translate computer-aided design when computer is rendered as engine that makes fast calculations?

Probably more important, though, at least from the vantage-point of the development of the Nupe language, is the fact that the adoption of the explanatory approach denies Nupe translators the opportunity to enrich their language. When they decide to borrow English terms without equivalents and make the phonological shifts that "Nupenise" such terms, the translators provide Nupe with specialised terminology it needs to cope with today's world. Unfortunately, Nupe translators seemed to borrow hesitantly, resorting to this potentially beneficial approach only when the terms involved could not be explained easily. This poses a serious problem in view of the fact that translators also hesitated to coin new words of their own. The Nupe translators did not come up with new coinages in any of the examples mentioned, preferring instead to use existing Nupe words even when such words did not make clear and precise translations possible.

\section{CONCLUSION}

Faced with local languages deficient in terminology, Nigerian language translators try their best to inform their public but often produce unsatisfactory translations. Most of the time they simply try to explain new or foreign concepts as best they can, and hope their audiences understand what is being said or referred to.

This approach is itself a big step forward, not only because target audiences need to understand the phenomena evoked in news bulletins but also because the approach is a necessary prelude to the actual development of the terminology required. However, even if the explanatory/definition approach translators resort to serves a useful purpose, it is not a satisfactory way to translate. Some may even refuse to accept the end-products as translations in the real sense of the word. There is thus a need for translators to go beyond the prolix paraphrasing they resort to at present, and develop better means with which to give adequate expression to modern notions and concepts.

Translators al one cannot be expected to do all of the language engineering work required, but they are in a good position to contribute meaningfully and concretely to the development of their languages - a responsibility they cannot take lightly. This, incidentally, was one of the conclusions arrived at during a national seminar held in March 1991 which brought together translators and other journalists working in the electronic media in Nigeria. However, this is a responsibility Nigerian language translators may not become fully aware of until they come to understand the real nature of translation activity. To do so, they will have to undergo systematic and specialized training: at present, only a few have benefitted from such training.

$$
\text { H.J. Jacob }
$$

Amadu Bello University, Zaria, Nigeria

\section{NOTES}

1. A Glossary of Technical Terminology for Primary Schools in Nigeria exists but it covers only nine Ianguages: Edo, Efik, Fulfude, H ausa, Igbo, Ijo, Kanuri, Tiv and Yoruba.

2. See report in The Guardian (Lagos), February 13,1991 , for the list of languages approved. 
3. Capo (1990: 6) defines "intellectualisation" as the "ability of (a) language to be used as a means of expressing the most abstract and most modern notions of science, technology, law and philosophy."

\section{REFERENCES}

Antia, Bassey (1990): "Independance and Language Planning: An Investigation of Terminological Strategies in Nigerian Languages", paper presented to the 11th Annual Conference of the Linguistic Association of Nigeria, Calabar, p. 6.

Capo, H.B.C. (1990): “Comparative Linguistics and Language Engineering in Africa", in E. N . Emenanjo (Ed.), Multilingualism, M inority Languages and Language Policy in Nigeria, Agbor, Central Books Ltd. in collaboration with the Linguistic Association of Nigeria.

Cyff er , N. (1977): “Language Planning and Universal Free Primary Education: A Kanuri Example", The Nigerian Language Teacher, vol. 1 no. 1.

Emenanjo, E. N. (Ed.) (1990): Multilingualism, Minority Languages and Language Policy in Nigeria, Agbor, Central Books Ltd. in collaboration with the Linguistic Association of $\mathrm{Ni}$ geria.

- - (1990): "In the tradition of the Majors: Lessons in Language Engineering for the $\mathrm{M} \mathrm{i-}$ nority language", E. N. Emenanjo (Ed.), Multilingualism, M inority Languages and Language Policy in Nigeria, Agbor, Central Books Ltd. in collaboration with the Linguistic Association of Nigeria, p. 89.

Hansfor d, K. J. et al. (n.d.): An Index of Nigerian Languages, no. 5 in the series Studies in Nigerian Languages, Accra, Summer Institute of Linguistic.

Jakobson, Roman (1959): "Linguistic Aspects of Translation", Brower (Ed.), On Translation, Cambridge, Mass., Harvard University Press, p. 234.

Jibril, Munzali (1990): "M inority Languages and Lingua Francas in Nigerian Education", in E. N. Emenanjo (Ed.), Multilingualism, Minority Languages and Language Policy in Nigeria, Agbor, Central Books Ltd. in collaboration with the Linguistic Association of Nigeria, p. 114.

Madugu, I. S. G. (1985): "Nupe Orthography", in A. Banjo (Ed.), Orthographies of Nigerian Languages: M anual III, Lagos, National Language Center, p. 25.

New mar k, Peter (1977): "Communicative and Semantic Translation", Babel, vol. 23 no. 4, p. 175.
Nida, E. and C.R. Taber (1974): The Theory and Practice of Translation, Leiden, Brill, p. 1.

Vinay, J.-P. et Jean Dar bel net (1958): Stylistique comparée du français et de l'anglais, Paris, Didier.

Wil I iamson, Kay (1990): "Development of M inority Languages: Publishing Problems and Prospects", in E.N. Emenanjo (Ed.), M ultilingualism, Minority Languages and Language Policy in Nigeria, Agbor, Central Books Ltd. in collaboration with the Linguistic Association of Nigeria, p. 142.

\section{Nine Theses About Anecdotalism in the Study of Translation (With Special Reference to Sherry Simon, Ed., Culture in Transit)}

\section{RÉSUMÉ}

Depuis des siècles, la théorie de la traduction comporte un caractère anecdotique qui est parfois critiqué par la traductologie des dernières décennies. L'auteur fait un tour de la question et conclut à la complémentarité des deux types d'approches.

\section{ABSTRACT}

For centuries, translation theory has had an anecdotal aspect sometimes criticized by recent translation theorists. This author examines this issue and suggests that there are two approaches which go hand in hand.

1. From its beginnings, translation theory has been insistently anecdotal.

Until the last few decades, in fact, theoretical pronouncements on translation have arisen al most exclusively out of specific translators' engagement with specific texts:

- $\quad$ In 55 B.C.E., Cicero tells us that he grew dissatisfied with the then current pedagogical technique of trying to reword and rephrase Latin authors, and decided instead to reword and rephrase Greek authors in Latin.

- In his 395 C.E. letter to Pammachius, Jerome defines his approach to translation in the context of an attack made on him by Rufinus for "mistranslating" a Greek letter for Epiphanius.

- In the 1170s, Burgundio of Pisa tells the story of growing enamoured of a Greek text by St. John Chrysostom while he was in Constantinople and of paying two scribes to copy it for him so he could take it home and translate it.

- In 1470, William Caxton tells several stories surrounding his translation of Virgil's Aeneid and the problems he faced.

- In 1521 and 1530, respectively, Erasmus and Luther defend their translations of the $\mathrm{New}$ 